Portland State University

PDXScholar

2-13-1975

\title{
The teaching of history in the secondary schools of Australia
}

Richard Townley Blaine

Portland State University

Follow this and additional works at: https://pdxscholar.library.pdx.edu/open_access_etds

Part of the Curriculum and Social Inquiry Commons, and the Educational Assessment, Evaluation, and Research Commons

Let us know how access to this document benefits you.

\section{Recommended Citation}

Blaine, Richard Townley, "The teaching of history in the secondary schools of Australia" (1975).

Dissertations and Theses. Paper 2287.

https://doi.org/10.15760/etd.2284

This Thesis is brought to you for free and open access. It has been accepted for inclusion in Dissertations and Theses by an authorized administrator of PDXScholar. For more information, please contact pdxscholar@pdx.edu. 
AN ABSTRACT OF THE THESIS OF Richard Townley Blaine for the Master of Arts in Education presented February 13, 1975.

Title: The Teaching of History in the Secondary Schools of Australia. APPROVED BY MEMBERS OF THE THESIS COMMITTEE:

Georde V. Guy. Chaiłman

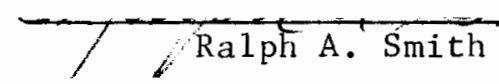

Jesse "L: Gilmore Australian students termanting their secondary education with completion of Form Four provided the major stimulus during the last decade for new curriculum developments in an organized study of man. To provide these fifteen-year old pupils with the necessary exposure to life for social adjustment underscored the debate between many social scientists and history teachers on the ability of their respective subject's focus.

Where in the middle of the last decade Australia found herself in the middle of a communication revolution, many students, ending their educations during mid-adolescence, did not finish the normal sequence of history courses. History's dominance in the study of man was soon cha1 lenged.

As a teacher and student in the Australian state of Victoria, it became soon apparent that many educational policies from abroad encountered a flexible if determined resistance. Arising from a different environment, many teachers and educators maintained that a few reforms 
or "enrichment" of history courses would more closely parallel contemporary needs than the more radical developments of the social sciences. A period of experimentation and uncertainty has persisted for at least the past ten years. A period which has not ended although many of the exponents of the extremes have retreated. History, a course which in 1965 was accepted by tradition, today is recognized and valuable for its own synoptic character. 
THE TEACHING OF HISTORY IN THE

SECONDARY SCHOOLS OF AUSTRALIA

by

RICHARD TOWNLEY BLAINE

A thesis submitted in partial fulfillment of the requirements for the degree of

MASTER OF ARTS

in

EDUCATION

Portland State University

1975 
TO THE OFFICE OF GRADUATE STUDIES AND RESEARCH:

The members of the Committee approve the thesis of Richard Townley Blaine presented February 13, 1975.

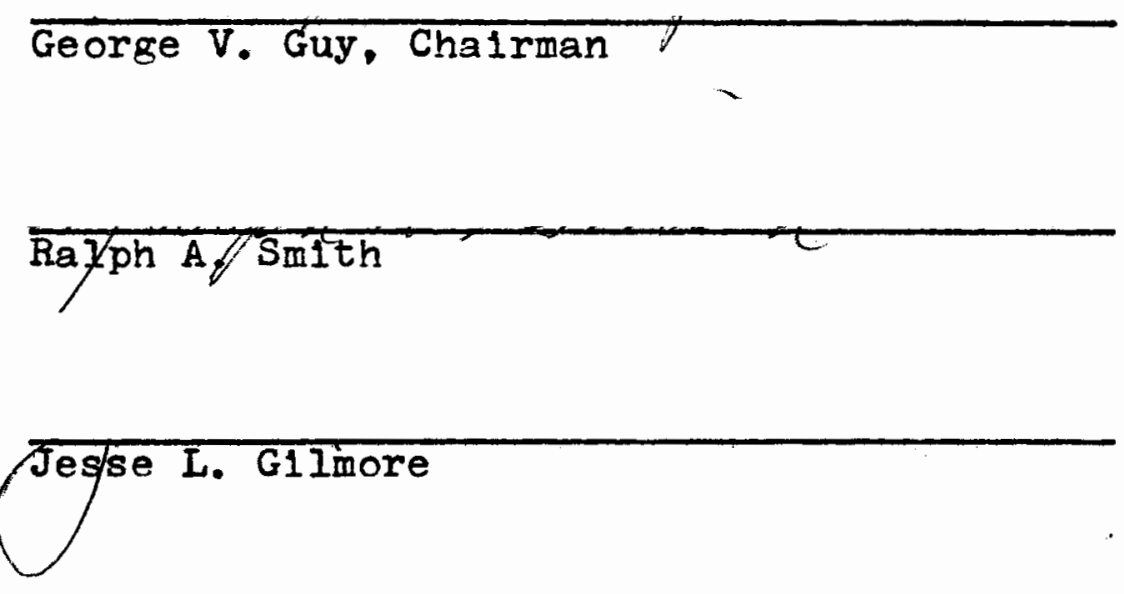

APPROVED:

Dr./John LInd, Head, Department of Foundations and Specialties Dr. Dav1d T. Clark, Dean of Graduate Studies and Research 


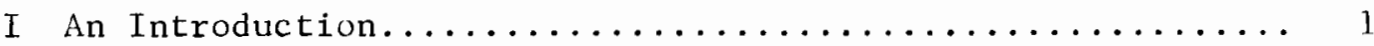

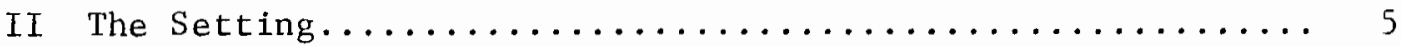

III The Climate and Forms I - IV $\ldots \ldots \ldots \ldots \ldots \ldots \ldots \ldots \ldots \ldots \ldots$

IV Some New Journals for Students and Teachers.......... 22

$V$ On the Past for Fifth and Sixth Forms.............. 25

VI The Tests - Fith and Sixth Forms.................. 29

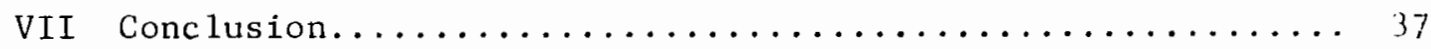

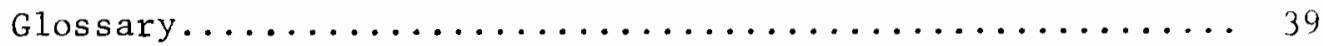

Footnotes.......................... 40

Bibliography............................. 44

Appendices............................ 47 


\section{CHAPTER I}

\section{An Introduction}

A qualitative comparison of history curriculums in the United States and Australia may confuse the reader if he is not aware of the different frames of reference operating in these countries. In spite of many similarities, both qualitatively and quantitatively, students experience different systems of education with different expectations.

American egalitarian education has tried to support the right of American youth to at least complete secondary education. Most states require students to remain in school until they are at least fourteen and many until they are eighteen. Although it remains difficult to enforce these statutes in many areas, inherent competition for jobs and success keeps students in school until graduation and far beyond into universities and colleges. Australian schools retain even today a more rigid academic reference in their secondary level schools. An education terminated at the end of the Fourth Form (Grade Ten) enables a student to become an apprentice, a bank teller, enter the armed forces or pursue careers usually open to an American with a high school education. Far fewer enter the university or other tertiary institutions than in the United States and their last two years in secondary school retains a more academic flavor than normally encountered by an American boy or girl.

The general view, if a diluted one, of education in the United States often draws criticism from abroad. Much of this criticism undoubtedly affects the study of history as this subject is viewed from 
an American frame of reference. D. W. Brogan, the British historian, commented on the value Americans have for history. "As long as American society remains individualistic, competitive, confident that the answers to the present are in the future, not in the past, it is going to take more than money to seduce the right men and women in adequate numbers away from the life of action."l The Australian, William Broderick, asked in his article concerning American education, "Sick Schools: Australian Perspectives," the question, "What knowledge is worth most?"2. Broderick follows a similar line of thinking as Brogan that if answers are to be found in the future and not in the past, then one should look to the natural sciences and not to the humanities for the more scholastic attitude.

Much of the change in Australian society and education emanates from the United States. The American influence is strong in all areas of education, not least of all the social studies. However, the goals of the social studies in which history has been preponderant in the United States have been at least more overtly stated than those for Australian history courses. During the early sixties the Educational Policy Committee underscored the movement of the social studies toward an active role:

The political order depends on the responsible participation of individual citizens; hence the schools have been concerned with good citizenship...The ability to recite the values of a free society does not guarantee commitment to those values. Active belief in those values depends on awareness of them and of their role in $1 \mathrm{ife} .3$

New social science programs evolved during the past decade in response to the needs of the curriculum. The trend to either create new programs or enrich the existing curriculum crossed the Pacific to Australia to be 
given a mixed reception. One noted Australian educationist noted:

"Reforms are proposed from time to time, and they do good. But too often they are simply a readjustment of the order or priorities of subjects.

This subject goes up in status, that one goes down." 4

As tradition alone could not justify the preponderance of history in the American social studies curriculum, it could not justify the multitude of history courses offered in the Australian educational system.

The skill aspect of the social studies, growing along the improvement of the social sciences, attained repute in articles like "Aims of Teaching the Social Sciences in Secondary Schools" by M. Williams and W. F.Connell. This article, like many of the time, was concerned that the social studies should do more than transmit a culture; they wanted them to emphasize the distinctuess of individuals and become a source of information and skills as we 11 as attitudes. 5

Our task here lies in the determination of the degree history courses in Australia adapted to a changing environment. The wealth of new materials and new concepts accompanied by a new awareness of the student's perception altered the way in which many history courses had been taught. Yet, whether in a state school or one of the many private schools in Australia, many teachers felt history was able "to give training in clear and logical thought and to develop the capacity for critical judgment. " 6

Again citing evidence from American sources, Australian educators realized their students, as American students, need to use contemporary materials and influences to develop skills and attitudes. How students perceived the past became a valid point of departure. The enormous 
amount of material available could be incorporated into the history class.

\begin{tabular}{|c|c|c|}
\hline The & World & The United States \\
\hline $38 \%$ & Newspapers and Magazines & $39 \%$ \\
\hline $35 \%$ & Television & $25 \%$ \\
\hline $13 \%$ & Teachers and Schools & $14 \%$ \\
\hline $8 \%$ & Parents & $12 \%$ \\
\hline $6 \%$ & Friends & $10 \%$ \\
\hline - & & - \\
\hline 7 & Total Sample & 89 \\
\hline
\end{tabular}

Another reason for reform of the social studies lies in the areas students believe they can best gain ".....analytical or evaluative competence." 8 The graph below compares the courses from which American students believe they can obtain the greatest amount of new knowledge.

$\begin{array}{lllll}\text { Science Courses } & 77 \% & \text { World History } & 30 \% \\ \text { Mathematics } & 72 \% & \text { Civics and Government } & 27 \% \\ \text { Literature } & 50 \% & \text { U. S. History } & 16 \% & 9\end{array}$

The preceding graphs, published in 1972 , represent briefly both the plight and the challenge to the teachers of history in the United States and, as we shall see, the teachers of history in Australia.

While it would be naive to represent the social sciences as replacing history within so short a time as one decade, they did help to stimulate a re-evaluation of the history program. Considering the vastness of Australia and the various factors lending themselves to either encourage or discourage reform, it is difficult if not impossible to generalize on the state of history teaching there. 
CHAPTER II

The setting

Our narrative considers the teaching of history in the Australian state of Victoria. This state was chosen for a number of reasons not the least of which this author lived and taught there. Other reasons exist for this choice which remain valid in their own right. Melbourne, the capital, is the second largest Australian city after Sydney, a very cosmopolitan center; it is often regarded as more English than London. Victoria, apart from Melbourne, supports its economy primarily through agriculture. The diversity of geography and employment lends itself to many different educational goals. The Victorian Education Department recognizes this diversity and grants a great deal of autonomy to its schools.

The freedom recently granted schools for the development of a curriculum suited to their needs has been hindered by a reticence to move away from the accepted standards whether in history or another subject. Prior to the sixties students progressed from Forms I through VI. They passed or failed the year depending on the yearly examinations in their courses which were governed and graded externally. Through suggested courses in handbooks published initially by the University of Melbourne and later by The Victorian Universities and Schools Examinations Board, schools grew accustomed to teaching these courses upon which their students would ultimately be judged. 
Gradually the yearly external examinations were removed and replaced by internal examinations. By 1967, the last year for the form Four examination, only the examinations for Forms Five and Six remained. The use of the handbooks, following the suggested courses for Forms I through IV, diminished somewhat more for the state schools than for the numerous private schools.

The prescribed courses in history became suggested courses with the elimination of the externally controlled examination system. Still, as late as $1967,75 \%$ of the Victorian students who completed history and geography courses during their first four years of secondary school followed the outlines provided in the handbooks. ${ }^{10}$ In history course outlines for the four years, V.U.S.E.B. suggested three alternate fouryear course schemes. 11

1. Scheme A:

a. Ancient Civilization (background to Western Civilization)

b. British History in outline - 55 B. C. - 1603.

c. British History in outline - 1603 - 1914.

d. History of the British Empire and Commonwealth.

2. Scheme B:

a. Making of Europe.

b. Expansion of Europe and development of middle classes.

c. Modern World (survey of present world)

d. History either of Australia and the Pacific, or of the British Empire and Commonwealth.

3. Scheme C:

a. The study of the ancient world contrasted with the present and including other aspects.

b. Life in Europe during the Middle Ages contrasted with today.

c. Expansion of the old world and the unfolding of the new.

d. History of Australia and the Pacific including a variety of aspects.

In the third scheme, the creators hoped by form Four that students would expand their perspectives enough to have an idea of the "social, economic and political development of the different kinds of territories which 
came to form the modern multi-racial, multi-lingual, multi-national commonwealth."12 Yet, referring to each of the proposed schemes, the authors said, "It is important in teaching this programme to keep the studies as concrete as possible."13

In order to draw some of the strands together to form a more accurate picture of junior and intermediate secondary levels in the social studies, we have to refer not only to the typical course outline as depicted above, but to the students themselves, and to the teachers themselves. An earlier graph comparing the sources of information on politics for American students with the rest of the world and the low rating schools received is perhaps reflected in a teacher's dependence on course outlines. For the student who left school after Form Four, it appeared necessary to the participants at the Burwood Seminar in 1967 for the course in history to consider the student as well as the content. Victorian teachers in 1967 , even with some leadership offered in the Victorian Education Department, preferred course outlines prepared by others.

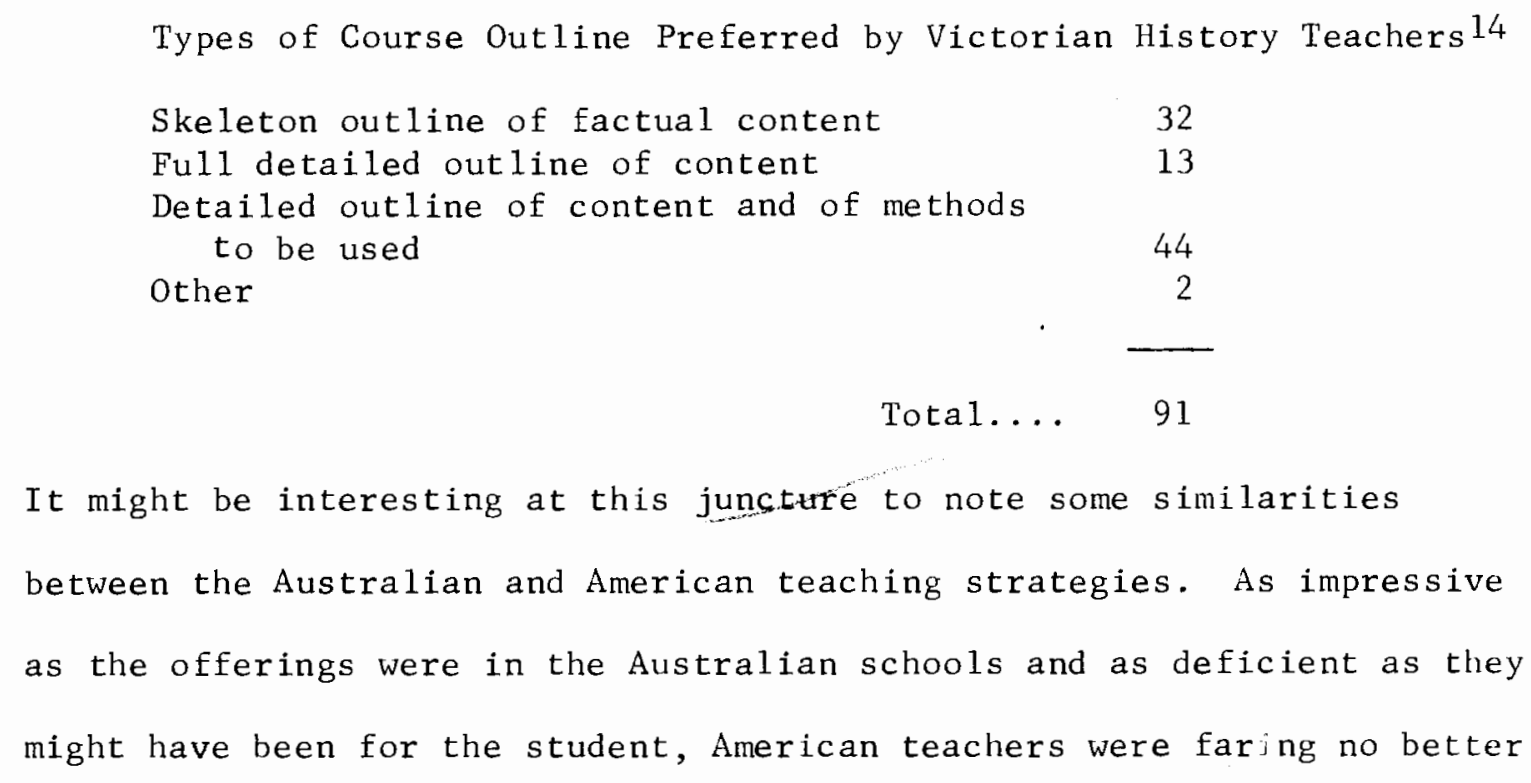


content - the factual material in relation to which learning is to take place."22 These men, who spoke at the two Burwood seminars, as heads of the subject committees and their departments, would become vitally concerned with the events of the period under scrutiny. These men cited as evidence for the inertia of the history program, the lack of emphasis on economic history at the senior levels, Forms Five and Six, and the minor emphasis on the arts and science in the junior Forms. It was not so much what the history did do, but what it did not.

The traditional pattern of chronological progress from year to year remains largely undisturbed. Many pupils still begin their journey with Neanderthal man and push onward through the ages until at last, in their final year at school, they burst triumphant into the twentieth century. Or at least some of them do. 23

Before we move into our next section, perhaps the reader will permit a moment's digression on the Australian educational climate. The purpose of the next few paragraphs lies in the necessity of comparing the Australian social metamorphosis with the dissolution of its insular geographic and cultural position.

Most sources agree with population statistics which cite the tripling of the Australian population since the Second World War as due in equal parts to natural increase and to the enormous influx of immigrants from primarily European countries. This rise in population and consequent change in composition from a country steeped in British tradition to one seeking its own place has received impetus from a variety of sources.

Since the last World War when Australia was besieged and in parts bombed, Australia has become, with the decline of British power, more dependent on the United States. As allies in Korea and Vietnam, and as 
co-signatories in SEATO and ANZUS, Australia became a lynchpin in American policy in the area. The discovery of large deposits of iron ore, nickel, uranium, zinc and oil attracted numerous foreign interests. The scant population needed the infusion from war-torn and refugee-congested European countries to operate the growing industrial and mining complex. Government needed competent men and women for the growing bureaucracy. Teachers during the fifties were content with content-oriented syllabuses. Teachers of the sixties and seventies were a mixed bunch. The needs of students seemingly changed in a short decade. The process of culture-creating has a very high priority for Australian educationists and teachers who realize how little students identify with their courses in British History or with the civilization of the Tigris and Euphrates.

Initially the conveners of the Burwood Seminars agreed that history and geography courses need "enrichment." This could be interpreted in a number of different ways, however. I believe, initially this meant these courses besides some integration were to include in their treatment of history economic aspects, attention to civic responsibility; in other words, they were to consider those who did not continue beyond the Fourth Form. Method and process were more fully considered.

After the second Burwood Seminar, the History Department within the Education Department of Victoria developed a Teacher's Guide. Designed primarily for the first four secondary forms, this short four volume work - The Use of Sources, The Nature and Study of History, Local History and a volume on resource centers - relies on much of the work of Edwin Fenton of Carnegie-Mellon in the United States. The child-developnent concepts of Piaget were a determining factor in these works, especially 
the fourth stage of the child's development where he is capable of logical sequencing. Thus, history as a conceptual study for younger forms would have certain problems with those students who are still in the concrete stage (certain amount of factual teaching could be considered). The original enrichment of the history courses included some form of student inquiry, i.e., greater emphasis on primary sources and documents. 
CHAPTER III

The Climate and Forms I - IV

In the next few years it may become easier to include Forms Five and Six in the same discussion with earlier four forms. However, the Fifth Form Leaving Certificate and the Sixth Form Matriculation were still governed by external examinations. The Leaving Certificate has been granted on the basis of internal examinations since 1972. Thus, it is too early to determine what, if any, organic changes may be made in the subject curriculum. The Matriculation standard remains for the present the basis for tertiary acceptance.

The publication of Edwin Fenton's course in the United States in 1966 and the course rationale fitted the expectations of the Victorian Education Department's History Department.

The overall objective of the curriculum is to help each student develop to the limit of his ability into an independent thinker and a responsible citizen of a democratic society. This general objective has been divided into four major parts: attitudes, values, inquiry skills and knowledge. The four groups of objectives cannot be divided in practice. Without knowledge of content, there is nothing for students to inquire about, without attitudes predisposing them to prefer a scientific mode of inquiry, they cannot inquire at all. Values in turn grow out of knowledge, attitudes, and inquiry skills. 24

Although Fenton's course appears per se most often in Fifth Form classes in history, it is regarded as appropriate for Third and Fourth Form students and in general it has affected the teaching of history in Victoria at a11 levels. 
Returning to the Education Department's Teacher's Guide, we can see the marriage of the Fentonian program and the child psychology of Piaget. The volume, The Use of Sources, underscores the necessity of the historian's craft; each succeeding generation must actively interpret the past. Through the emphasis on the "historian's craft," the authors of these pre-1970 volumes accentuate the method of history. Their intent here was to "enrich" the already present history courses. The student as an active participant made inroads in both the Victorian Education Department and in private schools as we soon shall see.

The Education Department outlined in The Use of Sources a possible approach to historical studies for the first four forms. The carefully structured program aimed to prepare a student to think formally in his study of history. The first two forms' courses worked as one unit promoting concrete method and skills which may be applied later. In Form 1 Department suggested material ought to be chosen which would help extend the student's perception of himself. This may take form in interesting stories, simulation games, or general discussions. The course for Form II developed the student's conception of cause and effect relationships in his own life. How this worked might be better explained in the words of a Social Studies Master at Caulfield Grammar School; for Forms I and II this program worked very well (I used it when I taught at Caulfield, a private school).

History never took the form of a 'History lesson'. But every opportunity was taken for historical research, whenever they could see the concrete realities of history. Excursions were the springboards here. A visit to Avalon led an assignment in which pupils did research into the story of the Austin family - and incidentally learned a lot of Victoria's early settlement. The trip 
to Pont Nepean was followed by research into the history of the forts there and at Queenscliff. Very little had been written on this and some ingenious lines were followed, including letters and phone calls to the Army, the National Trust and the Peninsula Historical Society. 25

The use of excursions and local studies for Forms I and II integrated local history as a vital part of the process. Henry Schoenheimer, a noted Australian educator and journalist, called the Caulfield Grammar program the "middle way" during a visit to the school.26 skills and concepts were emphasized in order for content-dominated courses to be more meaningful later.

For Forms II and IV, two of the authors of the Teacher's Guide, Colin Tonkin and Phillip Pledger, who are today inspectors for history in the Department, collaborated on a textbook and course, One World, which reflects much of the Education Department's philosophy for Forms III and IV. While borrowing heavily from the frame of reference conceived by Edwin Fenton, the authors make overt references to a student's perception in the context of the history course. Reviewing both Fenton's work and its effect on work as One World, the Victorian Education Department is satisfied "...that pupils in trial classes have shown considerable gains in the areas of procedural attitudes and values, hypothesis formation, independent inquiry and ski11 development."27 Coupled with the encouragement of the Burwood Seminars, the widely-heralded Fentonian program is used directly in schools for Fifth Form work and the Education Department has put the course on trial for other levels. Although Fenton's materials have been criticized, their distribution helped teachers realize that:

History is a well-established subject in both university and 
school curricula, consolidated by a good half-century as the recognized discipline for the study of man in society. 28

Yet the need for skill development and the consolidation of the student's frame of reference with the "recognized discipline," is, in effect, welded by necessity. "The young person needs help to understand the society in which he lives and to place that society securely in a time perspective."29 Concurrent with the proposals to enrich history courses existed an equal number for major reform of the curriculum. The study of man and his society would be more meaningful, many thought,if history as a subject were redefined. "History needs no separate existence for teaching or learning; it is a service study, not a self-sustaining discipline."30 While one may disagree with the validity of this statement, it was widely believed that "There is little sense of heritage, or awareness of the past detected in the present, among Australian children."31

They, the educators, did not disagree over the synoptic nature of history; their debate lay in the interests of the students and their ability to communicate meaningful experience in a way that permitted the student to relate to his or her environment. General Studies courses, based on an English model, were popular during the early seventies. If these courses emphasized that students who identified with something immediate to their existence, then history could take part by helping the student further research the subject. These teachers considered the many"strands" of the social sciences provided school leavers with a broader perspective of what lay before them. Through, not the recreation, but the relation of many of the influences centered on the structure of society in which they lived, it was felt that this clarification of relevant objectives in the eyes of the students would motivate their 
in their quest for the correct outline. In a study by Hines in California in 1960 , it was found that only $8 \%$ of the teachers used a topical approach while $76 \%$ used the chronological method and $75 \%$ gave each subject equal coverage despite its relative value for the study of history. And clearly $92 \%$ of the teachers followed a basic textbook for their classes with little use of outside materials. 15 In 1969 the examiner for history with the Educational Testing Service believed the social studies curriculum in American high schools had changed little in the previous 25 years. 16

In response to the changing times Australian educators met at two UNESCO-sponsored seminars on the social studies in Australia. Meeting at Burwood, Victoria, outside of Melbourne in 1967 and 1968, these men and women considered both the present state of social studies teaching in each of the Australian states and new ways to improve these classes. For ourpurposes we should note that the state of Victoria, the state under study, had $75 \%$ of her students enrolled in history and geography classes for an average of eight or nine forty-minute periods per week. 17 This compared favorably with the other Australian state educational systems.

In the paper summarizing the state of the social studies (history and geography courses), the authors, Bennett and Piper, cited a list of objectives for classroom teaching. It ought to be remembered that most students left secondary schools at the end of their Fourth Form year. The list included suggestions for the integration of history and geography, the dilution of materials for less gifted children, civics for training students for their civic duties, developing right attitudes for good social behavior, learning the structures and techniques of the social sciences, and finally, the ability to concentrate on the immediate environment. 18 
The curriculum planners both in the Victorian Education Department and in the subject committees within the Victorian Universities and Schools Examinations Board understood clearly their offerings would need revision within the upcoming years, and these took many directions. The watershed years of 1967 and 1968 actually begin our study. During this period new ideas and new influences were felt which seriously questioned the dominance of history in the study of society.

Like Burwood'67, Burwood '68 made it clear to these committees (subject committees) that their subjects were being closely scrutinized and that they should ensure that their houses were in order - that their claims to continued existence in the curriculum were sound and that their courses of study were consistent with the objectives they were supposed to achieve. 19

Although history was regarded as vital to the development of a student's horizon, other disciplines were believed able to make vajuable contributions. In other words, in the words of the educator, D. Mohony, "...the very hub of History's current dilemma is simply that it has for almost a century been charged with much of the formal social education of school children." 20

Yet, in spite of the courses outlined by V.U.S.E.B., in spite of some tradition, confusion on teaching objectives remained; also ".... that a considerable amount of disagreement and also a considerable lack of clarity exists, even among specialist teachers, concerning objectives, content, and methods. 121

With the proven predilection of many history teachers for more or less complete course outlines, due in not a small way to much of the pressures of the examination system, the Victorian Education Department inspectors for subject fields ascertained that the courses, the "official syllabuses, then, are, in effect, shorthand communication indicating 
curiosity.

The watershed years of 1967 and 1968 offered educators an opportunity to exploit the dissatisfaction with the dominant course in a student's social education, history. History, in the mind of a social science became a service study or an auxiliary. Alternative courses in the study of society were supported by many sources. These included a number of proponents in the universities of Victoria who founded their social science programs on models found overseas, i.e., Monash University. The CurricuIum and Research Branch of the Victorian Education Department revealed their interests through distribution of numerous brochures, reprints, and recommendations for class teachers. ${ }^{32}$ They have created social science programs, and they produce the monthly published and informative The Study of Society. Whereas research was once deemed a "part-time" activity of teachers of Form I through IV, it became a more professional activity.

The search for method to promote the acquisition of cognitive skills demoted content to a supporting position. This can be illustrated in the Social Studies Project developed by the Education Department and released in 1973. To be used for Forms I through IV, the specific aims may be found in the appendix. The course may be summarized as giving the student a comprehensive view of society through the social sciences. The emphasis on concepts, expanding the student's frame of reference according to his or her maturity, is achieved through "orchestrated" use of the disciplines. Using key questions, the student will observe how they approach the problem being studied. The three years covered in the content of the course expands the student's horizon. Course A deals 
with Small Scale Societies and moves on to Contemporary Australian

Society in Form III and concludes the next year with Comparative Studies of Other Societies, World Problems and Current Social Issues. These general course titles are supported with units, each designed to illustrate the concept and further the inquiry method. 33

The orchestrated, comprehensive approach to the social studies, overtly using the time perspective, seems at once more than just an enrichment of the history syllabus, yet not as devoted to the child's environment as the General Studies programs in use earlier. The project attempts to expand the child's reference beyond the single dimension of his own home with a more active teacher participation.

Even with the interest generated at the Burwood Seminars, the acceptance of new programs for the "study of man" has slowed since the peak around 1970-1971. On the wider Australian basis rather than on the narrower Victorian frame, the New South Welshman and noted social scientist, David Dufty, commented that the cycle of interest in new social science programs has declined in the past two years, since 1970 . He give seven interesting reasons to support this contention in article for the Australian Journal of Education, "After Burwood What?". 34 First, Dufty cites the Seminar as an instrumental meeting by bringing together men interested in the social sciences, for the first time. Second, to promote the social sciences, and continue their exchange of ideas, they founded a journal, NICSSE and a national committee. Yet, in Dufty's eyes, the seminar had a varied effect on curriculum innovation in the different states "...ranging from substantial in Tasmania to negligible in Queensland."35 He attributes this to the desire or lack of des re for 
changes in education to the level of resistance in the teachers' organizations of each state or the educational administration of each state. 36 The level of resistance cited by Dufty as the third reason for the decline of interest in the social sciences depended upon the strength of the teachers of the specialized courses in the higher Forms. This may have helped to delay the appointment of a state committee on the social sciences in New South Wales until 1969.37 The fourth conclusion arrived at by Dufty and closely related to the third was the objections raised on the creation of courses "... lacking in comparative and historical depth."38 The concern expressed in Victoria over the social sciences effect on the history curriculum is typical. This will involve us directly when we discuss the reaction of history teachers to the new programs. For the period beginning at Burwood and continuing until recently, this statement by Dufty has some validity:

In short, what began as an attempt to introduce elements of the 'new' social sciences into secondary schools has become a general reform movement to improve the study of society in schools at a11 levels.39

To illustrate the difference between two states, Dufty considered active research on the social studies to be still part-time and almost entirely eclectic, borrowing heavily from overseas. "We have gained much of the overseas ideas. Overseas visitors would find little here that is unique or well researched."

Dufty hoped that a national social science project would stimulate interest and develop resources suitable for the Australian secondary curriculum. Yet, in the final analysis, educators may be returning to many of the less radical departures proposed at the Burwood seminars. Perhaps 
the social sciences helped the history teachers restructure their plans

to accommodate more of the student's requirements.

Curriculum planner should start with the changes they expect in a child who has completed a course, rather than to start with a list of material to be covered. 40

Objectives are fast becoming a more serious preoccupation of history teachers.

It is the hope of the classroom teacher that his'students will be:

(i) We11 informed about society - its past trends, its present structure, its problem areas, its future challenges;

(ii) able to think intelligently about society from a number of viewpoints and using varied techniques of thinking;

(iii) interested in and concerned about society, people who are vitally alive in their own generation;

(iv) able to play with reasonable efficiency, imagination and integrity the various roles appropriate to a member of a world. 41

From the serious questions asked of history courses in the first four Forms of a student's secondary education to proposals for "enrichment," to history as a "service" study within the social science syllabus and perhaps, back to the history course, what is the situation today?

The V.U.S.E.B. Handbook's A, B and C schemes for Forms I to IV were lifted from the 1967 edition; they have not been changed since in any succeeding edition. In practice, however, the situation in the schools has altered maybe not as much as many social scientists had expected. In 1972 the Victorian Education Department surveyed the courses then being offered in their schools. 42 In First Form classes $54 \%$ continued to choose between schemes $A, B$ or $C$. In the Second Form nearly $65 \%$ pursued the 
V.U.S.E.B. courses. However, during the third year, almost $80 \%$ of the schools responded with courses in Australian History (this should not be confused with the Matriculation course which is considerably more difficult). In the Fourth Form as in the Third, the V.U.S.E.B. course had at least taken on a new guise. Asian History and One World Problems account for over $80 \%$ of the students' work. The remaining portion of the students at level were engaged in a variety of General Studies, integrated studies or social studies courses. (For a more complete breakdown of student enrollment, including Forms V and VI, please check the appendix.)

The last externally-controlled examinations for what is common $1 y$ known in Australian education as the Junior and Middle secondary school years was abolished in 1967. In the wake a number of reforms followed designed to change to a degree the existing condition of the courses offered. A number of influences inside the country and foreign militated the movement toward a redefinition of history. Today three approaches predominate for Forms I to IV. Their relative strengths and acceptance may fluctuate according to many of the factors Dufty cited in his article, "After Burwood, That?". The three, the General Studies program, the traditional subject-discipline approach and the Fenton Program, do not share the market in equal parts, nor would it be fair to attempt an appraisal of their futures in Australian education; yet, it would be interesting to see how an Australian educator measures each in the way each handles the numerous elements of the curriculum. Again, in the appendix the reader will find under Elements of the Curriculum comparisons of the three approaches. 
Some New Journals for

Students and Teachers

To transit from one age group to another and to pretend there are major innate differences, to insist that a Form Four student is less capable of comprehending a logical discipline, thus to judge them differently would insure they, Forms Five and Six, retain their separate posit ion. These two Forms have been kept structurally intact because the Leaving (Form Five) and the Higher School (Form Six) Certificates have been retained longer than the other certificates. It is incumbent here not to discuss the structure of the courses offered or their degree of difficulty or value, but to sponsor a connection between the study of society and man for all Form levels. This connection takes the form of journals founded and promoted during the sixties and early seventies which were designed to help students and teachers to use the historical method in the dissemination of content.

One channel used by the proponents of good history teaching was the Victorian Historical Association (hereafter called the V.H.A.) which sponsored and published three journals, the Historian, Agora, and the Journal of History for Senior Students. Even though the V.H.A. professed not to have a formal policy on curriculum, it has, nevertheless, influenced the teaching of history throughout Victoria. Two of the periodicals appeared after 1967, Agora and Journal of History for Senior Students. 
The Agora, appearing in 1967, in its very readable format, devotes its pages to the exchange of information, trends in teaching history and materials available. Often actual syllabi and lesson plans for all levels are published. While the publications have a practical purpose, they reprint articles from overseas periodicals they consider important. One article, reprinted from the Phi Delta Kappan in the Agora underscored with some irony the essence of history for secondary students. The title of the article, "Six Myths Which Delude History Teachers," epitomizes the changing face of history teaching.

1. There exists an entity called history.

2. History is, somehow, bound up with being a good citizen.

3. Students really can't think about history until they first have the facts.

4. History means diplomatic, political and military history.

5. It is possible to use history as a means of nationalistic indoctrination and also be scholar1y.

6. The final myth is that the only conceivable way of teaching history is to begin.with 1607 and work your way to the present. 43

Perhaps this article in no way reflects the opinion of the publishers.

On the more immediate classroom level, the V.H.A. journal, introduced in 1970 , for senior students has this objective:

This journal has been established to publish survey articles, articles illustrating general themes and source material relating to the history courses normally taken in the fifth and sixth years. 44

The issues thus far have been devoted to one history subject per issue. Devoting one issue to a particular subject provided students with more 
breadth at any one time than they normally would encounter. The journal also accentuates history's dependence on other disciplines for accurate interpretation. An example, "Geography and Politics in North and Central Italy," written by Betty Malone, shows the influence of geography on the development of the Italian states during the Middle Ages and Early Modern Times. With four or five articles pertaining to this subject, many aspects are covered.

The V.H.A。 encouraged and helped organize through its offices the foundation this past year of the National Association of History Teachers (1972). The association was formed belatedly "to facilitate and extend the exchange of publications and information between state history teachers' associations." 45 This association will eventually publish its own journal and hold annual conferences. The V.H.A. actively encourages the reform and adaptation of new history courses through not only its own publications, but has extended its sources nationwide.

Hopefully, in this very brief section, the reader will ascertain the artificial delineation between the type of attitudes which are perpetuated in this perusal of Australian history courses. It would be incorrect to simply state that history is more valid for more mature students and less mature students can gain decidedly less. Perhaps the fact that different bodies have administered each side of the division or that different expectations are promulgated for the different levels will account for the problem. 


\section{CHAPTER V}

On the Past for

Fifth and Sixth Forms

We moved earlier into the Fifth and Sixth Form work with our brief investigation of some of the observations on how to use the "historian's craft" and with some of the objectives promoted by the Victorian Historical Scoiety. More direct intercourse with history teaching and learning at these two levels has been avoided thus far due to two basic reasons. First, the study of history at the Fifth and Sixth Form year has a more academic flavor than the study of history earlier. This may be due to the retention of the external examinations until recently for Fifth Form and still for Sixth Form. With large numbers leaving school at the end of the Fourth Form, the remainder had a good opportunity to pursue their education into their Sixth year or tertiary level. Second, these students being older, having passed through four years of secondary education ought to have the background necessary for a humanistically-oriented, content-rich history course.

One cannot argue with the selection of history courses offered at the upper two levels of secondary history study. 'At the Fifth Form, students have the opportunity to study with some depth American, Asian, British, Greekand Roman and Modern European histories. At the Sixth Form candidates for Matriculation can enrol1 in Australian, Eighteen Century, Greek and Roman, and European (1300-1600) histories. In the variety of 
courses available, Victoria leads the other states. In 1974 American History was added.

The course instructions for Secondary students going to press year after year in the Handbook of Directions and Prescriptions define their subjects for content-oriented classrooms. The general objectives cited in the Handbook and repeated in other editions reveal the finely-honed understanding expected of students. The examiners and editors of the Handbook refrain from making too definite a statement on the implementation of the objectives or goals of the history course in specifics.

The statement (on objectives) is essentially a definition in general terms of the kinds of skills and understanding which it is believed this particular discipline should be imparting to students, and is not intended to be in any sense a comprehensive statement of objectives in the teaching of history in schools. 46

The word "imparting" in the above quotation may be an unfortunate choice, but it summarizes the ambivalence of the student's role. The objectives, well worth citing, accentuate the maturity expected and, as we shall. see, often not attained.

\section{Knowledge}

Accurate knowledge of the most significant events and personalities of the period under study, in sequence and in context - that is, familiarity with the factual evidence upon which explanations or judgments about the period must be founded.

2. Comprehension and Interpretation

The ability

(i) to understand the existence of problems;

(ii) to see the relevance of evidence to problems;

(iii) to understand the historian's arguments in relation to a particular problem; 
2. Comprehension and Interpretation (cont.)

(iv) to appreciate the provisional nature of historical judgments ;

(v) to consider historical problems by defining their nature, selecting relevant evidence and relating evidence and argument closely. (In general, evidence of this ability would be expected mainly for high honours.)

\section{Expression of Ideas}

The ability to express views and arguments clearly and grammatically, using correctly the terminology of the subject.

4. Knowledge of the Historian's Craft

Some acquaintance with various types of historical evidence and some awareness of the problems involved in evaluating different kinds of source material.47

If the courses preceding Fifth and Sixth Forms developed the perspective of students with the view of "relating evidence and argument closely," perhaps more students than those receiving high honours would qualify in this critical skill: Critical thinking.

With the recent deletion of the Leaving Examination as opposed to the earlier abolition of the other examinations for Forms I to IV, alternative causes to the ones mentioned have not really been developed for Fifth Form. Although Social Studies for Sixth Form exists, it deals primarily with contemporary politics and international relations. A real problem facing contemporary students during these two years lies in the growing isolation of the courses in the long run of their education. Are they actually understanding the problems and their origins in Asian affairs or American historical events? Are the courses for the first four Forms leading into work during the last two years? How prepared is the 
student for the course and how prepared are the teachers to guide the students rather than to simply impart knowledge?

Coupled with the preceding problems of student preparation for lifth and Six Form history courses is the opinion here that a student who has developed sufficiently his cognitive skills and to a degree his effective domain during the first four years of secondary education should be able to generate his own ideas on the time perspective and propel them in a frame of reference suitable for a maturing mind. The courses studied then ought to encourage the active intellectual cooperation of the student, yet insure references supplied him will permit reflection of and on many historical views.

As it is, many students succeed in spite of the system. Their native ability, some good teachers, their curiosity and materials available to them help them place both themselves and past events into proper perspective to understand the interpret the present in light of the past and hopefully encourage an optimistic - with a view to reality out look. 


\section{CHAPTER VI}

The Tests - Fifth and Sixth Forms

The last six or seven years of testing in the upper secondary forms has at times confounded both teacher's and examiner's patience. Neither is really able to offer a solution to many of the abuses of the examination system, except doing away with the examination (as Leaving in 1972). While there are many papers of excellent quality, others just get by. Yet, the dilution of material may only postpone serious academic achievement or worse, cancel it for those who not proceed to the university. The administrators of the examinations, V.U.S.E.B., through the subject committees recognized this defect in the system and are proceeding to make the different history fields more uniform in standards. The state

of flux prevalent for the past few years has hindered overall uniformity. Many of the obstacles hindering progress lie in some of the more recent innovations. In the V.U.S.E.B. Examiner's Reports, an annuallyproduced compendium of pessimism, the examiners not only decry the poor quality of the student's scripts, but his inability to compete with the computer and the new grading system. The New "A" through "H" system has taken the place of the old Honours sytem. In the new system " $D$ " is the lowest grade one can receive and still be considered for tertiary education. The computer drives a hard mechanical bargain. It must have a certain number pass and often disagrees with the examiner's assessments. 
Here are the comments made on two sample scripts in Eighteenth Century History. In each script three examiners have given briefly their view of what it takes to pass the examination. (Each script in every subject is examined by three persons who teach the subject; they must arrive at a consensus on the quality of the paper.) A grade of "D" differed by $7 \%$ for the computer versus the examiners.

1. A paper which just obtained Grade D.

(a) Computer Grade D 22255/'T 43\%

Examiner 1. Last two questions threadbare, but was able to present main features.

2. Agree.

3. 2a: Covers all aspects, but very thin. 10: Loose, slight, emphasis wrong. Paper overall simply too thin.

The computer assigned a grade of " $D$ " to a student who in the opinion of the examiners did not qualify to pass. The next comments relate to a student who did pass, although just barely.

(b) Examiner's Grade D $21993 / \mathrm{J} \quad 50 \%$

Examiner 1. Trying to be relevant, but knowledge superficial and limited.

2. Agreed. +1 for documents.

3. 13a worth a pass. Passable as a whole.48

Teachers in the Australian schools often governed their courses with a view to the percentage of their students who pass each year in so doing, determined their personal success. Led by pass percentages and inadequate preparation, teachers and students often have a hard time living up to the standards outlined earlier. 
The results of the exams correspond with the frame of reference of the student in one more respect - numbers - and again, with recognized pass percentages. The trend over a period of five years reflects students moving toward subject areas of more immediate relevance. The corresponding shift from one subject to another does not represent a higher standard for the subject with fewer candidates. The quality of papers in the more "relevant" subject may not rise either.

The everyday influences experienced by students through television, newspapers, magazines, radio and friends lend themselves to American, Asian and Australian histories. American History increased its enrollment from 2600 in 1967 to over 4100 in 1969 , and 4500 in 1970.49 The increase of Australian History at Matriculation is even more spectacular averaging 15\% increase between 1967 and 1970, leveling out after 1970 with over 10,000 candidates.50 Asian History also rose in relative numbers over the same years. Quantitatively, these subjects were rising in popularity; qualitatively, it has been suggested they were losing some of their academic flavor.

In 1968 and 1969 the Victorian H.S.C. Australian History examination was criticized as too searching for young students and contained too high an emphasis on the Twentieth Century. "The paper distressed those students with compartmentalized knowledge."151 In those papers the students were found lacking in their eomprehension of how to argue, in sustaining an idea, and were basically unhistorical in their frame of reference. The following years saw a "searching examination to alleviate the distressed students. This led to the loosening of standards and the rephrasing of questions so today, in the words of an examiner, the subject 
is often consided a "soft option."52 The examiners rationalized the results: "...the function of the examiners is to attempt to rank candidates, not to measure them against absolute standards."53 Yet:

These requirements, set down by the V.U.S.E.B., sometimes obscured some very bad performances among candidates. Mr. Evans (Chief Examiner) stated that there was some very poor work and that the actual standard of achievement was not very high. The reasons may be numerous: Inter alia poor teaching and study practices and/or the prescribed course of study. 54

The practice of relating parts of the course to present social, political and economic conditions may, if unbalanced, lead to a distortion or loss of historical perspective. 55

These two comments were expressed at the same committee meeting, as is footnoted: The relation between the two is greater than meets the eye, and six years of work may be involved and relevant.

Evidence of "presentism" and historical perspective noted in the 1971 examination question on C. D. Rowley's The Destruction of Aboriginal Society helped quickly determine the better student who "...reflects a sense of balance between historical consideration and related social and mora]. issues." Yet,

Many answers condemned society, its politicians and other groups in the Nineteenth Century in their attitudes toward the Aborigines. Yet the reaction of these groups at this time toward the Aborigines may have been a response to an entrenched attitude, viz., that because the Aborigines were not cultivators, they had no land rights. 56

Haziness of perspective may result from another source; the habit of examination to contain similar questions each year leading to the spoon-feeding of prepared answers by teachers or the preparation of answers before the test by ambitious, but misguided students. The sample questions to follow cover similar historical ground; their phrasing changes 
slightly from year to year. These questions could be interpreted in such a fashion to permit excessive latitude in the latter years while being more demanding earlier. 57 The examples are:

1. Questions concerning Governor Macquarie and the Bigge reports:

1967: 3. (a) "To what extent did the Bigge Reports mark the end of an era in the history of New South Wales?"

(b) "He (Macquarie) confidently expected not only the approbation of his sovereign, but also the applause of posterity for the purity of his motives and the rectitude of his actions." Comment.

1968 3. "To what extent did Macquarie's autooratic behavior stem from his personality and to what extent from his instructions?"

1970 4. (a) "What caused the development of factions in the society of New South Wales in the period 1800 to 1821 ? How did facionalism affect the appointment of a Commission of Enquiry in 1819 and the report of Commissioner Bigge?"

19714 4. "How did the problem of reconciling the requirements of a penal settlement with the development of a free colonial society arise during the administration of Governor Macquarie? How did Commissioner Bigge propose to solve the problem?"

2. Questions concerning Edward Gibbon Wakefield and the free emigration of the $1830^{\prime} \mathrm{s}$ and $1840^{\prime} \mathrm{s}$ :
1967 4. (a) "In what ways did the immigration of free settler in the $1830^{\prime} \mathrm{s}$ and $1840^{\prime} \mathrm{s}$ affect the social and political development of Australia?"
(b) "'Wakefield was important as a publicist, not as a policy maker.' How useful is this distinction in an assessment of Wakefield's contribution to the settlement of Australia?"
1968 4. "Men emigrate in hope..."
What were some of the hopes of migrants to Australia of the $1830^{\prime} \mathrm{s}$ and $1840^{\prime} \mathrm{s}$, and to what extent were they fulfilled?" 
1970. 7. (a) "How and for what reasons did Edward Gibbon and his supporters attempt to remove the stigma of pauperism from emigration? How did the theories and activities of the Wakefieldians affect the development of the imperial emigration policies concerning the Australian colonies?"

1971 5. (b) "What circumstances produced the first mass migration of free men and women to the Australian colonies during the $1830^{\prime} \mathrm{s}$ and $1840^{\prime} \mathrm{s}$ ? What did the migrants contribute to colonial society?"

(c) "My country I am sore at heart for thee! And in mine ear, like a storm-heralding breeze, A voice against thee gathers warningly. Lo, in what hands seem now they destinies! Hands grasping a11, through party means to seize Some private benefit: and what should be They freedom's dawn, but gives acendancy To lawless squatters and the hacks of these! Woe waits a lend, where men are wise or brave For naught but self.... (Charles Harpur, 1845)

'What circumstances provided this radical judgment on the squatters in New South Wales? How would a squatter have replied to the criticism?"

Since a student needs to choose only three essay test questions, in addition he must complete the document and objective sections; however, the essay section constitutes the bulk of the test. The likelihood of similar questions appearing each year will assure the "discerning" candidate at least a "D" grade. Each year the same books for discussion by the same authors are included: Blainey, Russe 11 Ward, and Kiddle, et al.

Prepared answers presumably will be with us a long time, but answers prepared by the teacher to which the pupil apparently contributes nothing - certainly not understanding - seem to be the ultimate academic betrayal.58

Examiners frequently state characteristics commendable in history students. They note the ability of efficiently used documents, experience in discussion, having used a variety of texts, the ability to write concisely, and to use relevant knowledge.59 However, with the appearance of 
the "soft option," and the continued existence of doubtful examination techniques, it is uncertain how these comnendable recommendations will ever be realized in the average student.

Australian History, the course presented in parts of the preceding discussion, is particularly pertinent for the study for another reason. As the Matriculation history course with the greatest number of candidates, over 10,000, its influence will affect the teaching of all history subjects. 60 The Permanent Advisory Committee for this H.S.C. Australian History course is making allowances in the examination itself. In the hope of coordinating their activities this committee will:

(a) Review the syllabus in their subject from time to time in the light of developments within the field of history or in the methods of teaching history, recommend to the Standing Committee that appropriate adjustments be made;

(b) From time to time to produce a biliographical essay to guide teachers through the latest research and problems in their subject; and

(c) Specify lists of primary source material which teachers may be able to use in relation to particular sections of the course and indicate how the sources recommended can be used. 61

Teachers are concerned more than ever about their roles within the system and the criterion of their subject as they see it and as others see it. They, the teachers, and the professional researchers and the curriculum builders should have a close relationship to work in harmony. The researchers may cite values, objectives, attitudes, and relevant materials teachers may incorporate in their classes, but an unharmonions relationship will bring the best intentions and ideas to naught. The creators of the new or revised syllabi ought not to go too far initially. They both, researchers and teachers, want "...to have these values 
studied historically, and examined analytically, but we (the teachers) are not prepared to have stands for or against them built into the curricula."62 Teachers are wary of teaching to any set pattern of values. They want to study these values in the context of their times, individually, not as "...examples to be exploited by campaigners for causes."63

History teachers are not engaged in teaching a set of generalizations or assumptions about society. Instead, we (the teachers) encourage students, if necessary inch by inch, to learn to make their own interpretations. 64

Not only does history pass on a heritage, history is instrumental in comprehending the contemporary world through the promotion of concepts and skills.

The ability to place onself and his society in the perspective of time ought to be the goal of any educated man. The study of history cannot be started and ended in a year or two and expect the majority of students to gain substantially. If the goal of secondary education regarding history is to create a foundation upon which the educated man may build, then the process must begin earlier than the Fifth or Sixth Form. History may not be the best subject for building the necessary foundation during the early secondary years of school, but to not proceed to history with some depth would leave the student with a structure with little meaning. Social science and history can work together without the suspicion so well exaggerated by Alfred Eisenstadt.' He said of the social scientists who

...vigorously postulate hypotheses, define areas for inspection, set up charts, classify IBM cards, make the chemistry of human action a matter of quantitative analysis... If the historian sees method in their madness, he also suspects madness in their method. 65 


\section{CHAPTER VII}

\section{Conclusion}

From the point of view of comparative education, our study of history teaching in Australian schools reveals similar pressures at work, similar points of departure for educators there as at home. Yet, there are differences. While rapid communications tend to break down many barriers, educational systems may retain different priorities. Starting from the educational system most often referred to as the English "model," Australian education shed some of the former rigidity of the decades preceding the 1960's. In abolishing many of the external examinations, certain academic attitudes developed new or reformed teaching objectives.

During the past decade, when history came under fire as too dominant in the study of man for secondary-aged students, many educationists sought to enrich this subject through the incorporation of principles from other disciplines. Other educators sought to restructure completely the study of society. The work of Edwin Fenton corresponded neatly with the ideas of many Australian teachers.

New pressures under many guises engendered many new ideas in the teaching of history. No longer was the subject to take itself for granted. New journals not only promoted the subject for teachers, but for student as well. Problems remain, the examinations at the Matriculation year tend to use similar questions each year, and alternative methods of examining are still in the developmental stage and not doing well at that. One of 
the strengths of the examination system laid in its ability to maintain a coordinated progression of study from Form I through Form VI. Today secondary schools have a great deal of autonomy which is good, but does not always lend itself toward some uniformity.

Certain history courses, Asian, Australian and American, are becoming more popular for contemporary reasons. The teaching of these courses is susceptible to many preconceived ideas. For the other history courses much is being done to halt their decline in popularity. The 1970's in Australian education will be interesting; the formal disciplines have regrouped and reformed their objectives. 


\section{Glossary}

Form: Equivalent to the American term, Grade as it pertains to the chronological ordering of students, i.e., Form I is the same as Grade 7.

Form Master or Subject Master: A teacher.

Intermediate Certificate: Received upon successful completion of Form IV work. External control eliminated in 1967.

Matriculation or Higher School Certificate: Successful Matriculation after Form VI made the candidate eligible for University or other tertiary education. Still operative.

Social Studies: Technically a Form VI course in Politics and International Relations; elsewhere it is subject to as many interpretations as in the United States.

Victorian Universities and Schools Examinations Board: As the governing body for university entrance, it has power to administer examinations granting the certificates cited earlier. Today it controls only the Matriculation examinations; however, its influence is widely felt. It publishes both the Handbook of Directions and Prescriptions and The Examiner's Reports. 
Footnotes

1 D. W. Brogan, "Unity, Liberty and Education," in American Education in Foreign Perspectives, ed. by Stewart E. Fraser (New York: John Wiley and Sons, Inc., 1969) p. 82.

2 William Broderick, "Sick Schools: Australian Perspectives," in American Education in Foreign Perspectives, ed. by Stewart E. Fraser (New York: John Wiley and Sons, Inc., 1969) p. 241.

3 "The Educational Policies Commission Issues a New Statement on the Aims of Education," in Turning Points in American Educational

History, ed. by David B. Tyack (Waltham, Mass.: Blaisdell Publishing Co., 1967) p. 409-410.

4 A. D. Pryor, "The Role of the Teacher in Australian Society," in Counterpoints: Critical Writings on Australian Education, ed by S. D'Urso (Sydney: John Wiley and Sons, Australasia Pty. Ltd, 1971) p. 78 .

5 M. Williams and W. F. Connell, "The Aims of Teaching the Social Sciences in Secondary Schools, in Counterpoints: Critical Writing on Australian Education, ed. by S. D'Urso (Sydney: John Wiley and Sons Australasia Pty. Ltd., 1971), p. 168.

6 T. W. G. Miller, "Secondary Education," in Fundamenta1 Issues in Australian Education, ed. by A. G. Maclaine and R. Selby Smith (Syaney: Ian Novak, 1971) p. 211.

7 Richard Remy, "High School Seniors Attitudes Toward Their Civics and Government Instruction," Social Education, Vol. 36 (October, 1972) p. 594.

8 Ibid. p. 594-95.

9 Ibid. p. 594-95.

10 D. M. Bennett and K. J.Pi.per, Part I The Present Situation in and the Status of, the Teaching of Social Sciences Seminar on the Teaching of Social Sciences at the Secondary Level, Melbourne, 28 August - 8 September 1967. pp. $45 \mathrm{ff}$.

11 V.U.S.E.B., Handbook Forms I - IV (Carlton, Victoria: V.U.S.E.B. Courses of Study Forms I-IV, 1971, A. H. Massina and Co. 1971) pp. 104-11.

12 Ibid. p. 108.

13 Ibid. p. 105. 
14 P. H. Partridge, et al. Social Science for the Secondary School, (Sydney: Ian Novak, 1969), p. 44.

15 Paul Hines, "World History: The Growing Focus on World Cultures," in Social Studies in the United States, ed. by Benjamin Cox and Byron G. Massialas (New York: Harcourt, Brace and World, Inc., 1967) p. 132 .

16 Elisabeth G. Kimball, "A Survey of the Teaching of History and Social Studies in Secondary Schools," School and Society, No. 98 (April 1970), p. 246.

17 Bennett and Piper, Op. Cit., p. 11.

18 Bennett and Piper, Op. Cit., p. 12.

19 Colin Tonkin, "The Early History of the Secondary Social Project (Victoria)", (a draft of his article-on loan), pp. 9-10.

20 D. Mohony, "History's Future in the Secondary School," Historian No. 24 (October, 1972), p. 24.

21 P. H. Partridge, Op. Cit., p. 43.

22 Ibid, p. 21.

23 P. H. Partridge, Social Science... p. 22.

24 E. Fenton, "Carnegie-Mellon University Social Studies Curriculum Project," Social Education Vo1.XXXVI (November, 1972) p. 735.

25 Donald Wirth, "History Lesson"(Unpublished social studies extract, Sept. 1970).

26 Conversation with D. Wirth on the Social Studies at Caulfield Grammar School, October 1973.

27 W. Lamb, "Planning a History Course - The Fenton Model and Some Others," Agora IV (November 1970), p. 13.

28 Colin Tonkin, Op. Cit., pp. 10-11.

29 Ibid. p. 11.

30 J. M. Graham, "History", in Teaching about Society, D. G. Dufty, ed. (Adelaide: Rigby Ltd., 1970) p. 164.

31 Ibid, P. 160

32 Personally received from Curriculum and Research via Mr. Richard Barnden material on the Social Studies which could by weighed by the kilo. 
33 Curriculum and Research, Victorian Education Department, Senior Social Science Project, pp. 9-10 (on loan from C. Tonkin)

34 David G. Dufty, "After Burwood, What? A Study in Curriculum Innovation and Evaluation, "The Australian Journal of Education XV

(March 1971), p. 86.

36 Ibid, p. 91

37 Ibid.

38 Ibid.

39 Ibid.

40 Peter West, "History and Social Sciences: Searching for Ot jectives," The Forum of Education XXXI (September, 1972), p. 148

41 Ibid.

42 G. P. Russel1, "The Place of History in the Social Studies A Search for a Rationale," Agora, Vol. VII (June, 1973), p. 83.

43 S. Samuel Shumis, "Six Myths Which Delude History Teachers," Agora (reprinted from Phi Delta Kappan) Vol. VI, No. 3 (June 1972) p. $\overline{86 \mathrm{ff}}$. p. 25 .

44 Journal of History for Senior Students, Vol. III No. 2, 1972,

45 Agora, National Association of History Teachers, Vol. VI No. 4, (August 19:72), p. 150 .

46 The Victorian University and Schools Examinations Board, Handbook of Directions and Prescriptions for 1969. (Carlton: A. H. Massina \& Co., 1969), p. 258.

47 Ibid.

48 Comments on Grade "D" standard for Eighteenth Century H.S.C. scripts found in the box of sample scripts found in V.U.S.E.B. warehouse in melbourne.

49 V.U.S.E.B. Handbooks for the years 1967-1971.

50 Ibid.

51 V.U.S.E.B., Reports of the Examiners for 1968 (Carlton: A. H. Massina \& Co., 1969), P. 77. 
52 M. J. Elliott, Australian History, Report of Meeting with Chief Examiner, Mr. Lloyd Evans, Parkville, Victoria, 24 March 1972. Agora Vo1. VI (April, 1972), p. 77.

53 Ibid.

54 Ibid.

55 Ibid., p. 78

56 Ibid., p. 78

57 Questions taken from Australian History H.S.C. Examination for years 1967, 1968, 1970 and 1971.

58 V.U.S.E.B., Reports of the Examiners for 1971 (Car1ton: A. H. Massina, 1972) p. 156

59 V.U.S.E.B., Reports of the Examiners for 1969 (Carlton: A. H. Massina, 1970), p. 32 .

60 G. P. Russe11, "The Place of History..." p. 84.

61 M. J. Elliott, Op. Cit. p. 80.

62 F. Ford, "The Victorian Historical Association and Curriculum Change," Historian No. 24 (October, 1972), p. 20.

63 Ibid.

64 Ibid. p. 31

65 D. Mohony, "History's Future...", p. 27. 
Bibliography

Primary Sources and Acknowledgments

I am deeply grateful to a number of men and women who helped me in the course of my research. Besides their very positive criticism of various drafts of this thesis, they directed me to new sources and they were generally interested in some of the comparisons drawn between the teaching of history in Australia and the United States. Among those educators are a number who have already been cited in the footnotes. Colin Tonkin, Inspector for History in the Victorian Education Department, offered me both his tine and numerous drafts of his work, Senior Social Science Project. Donald Wirth, my counterpart in the Social Studies Department at Caulfield Grammar School in Melbourne, helped me with discussions directly concerning this paper and with his cooperation as a colleague. He also provided me with a copy of his unpublished "History Lesson" cited in the footnotes. Mr. Richard Barnden and Mr. Ross Cleaves of the Curriculum and Research Branch of the Victorian Education Department sent me material by the kilo for both work on my thesis and as a teacher. Last, but not least, Mr. Norm Dobson, my advisor and Sub-Dean of the Faculty of Education at Monash University.

The Victorian Universities and Schools Examination Board both publishes the Handbook for Forms I - IV, Handbook of Directions and Prescriptions and Reports of the Examiners (Carlton: A. H. Massina \& Co.) annually and they, V.U.S.E.B., retain sample scripts of each test. In providing me with scripts, examinations, and advice on how to interpret their publications, they performed an invaluable service. 
Secondary Sources

Bennett, D. M. and Piper, K. J. "The Present Situation Concerning the Teaching of the Social Sciences in Australian Secondary Schools (Summary)" Education News Vo1. XI No. 6, December 1967, pp. 7-13.

Bessant, B. "Drastic Changes in Matriculation Histories, V. H. A. Representative Report." Agora Vol III, No. 2, June 1969, pp. 46-51.

Blackford, K. R.: "Concepts in Secondary School History." Agora Vo1. V, No. 3, July, 1971, pp. 94-99.

D'Urso, S. ed. Counterpoints: Critical Writing in Australian Education. Sydney: John Wiley and Sons Australasia Pty. Ltd. 1971.

Dufty, D. G. "After Burwood, What? A Study in Curriculum Innovation and Evaluation." The Australian Journal of Education Vol. XV, March 1971, pp. 73- 94 .

Ennor, Sir Hugh. "Opening Address: Australian UNESCO Seminar on the Teaching of the Social Sciences." Education News Vo1. XI, No. 6, December 1967.

Fearon, F. "The American Revolution: Problems of Interpretation," Historian. No. 24, October 1974, pp. 1-10.

Fenton, Edwin ed. Teaching the New Social Studies in Secondary Schools. New York: Holt, Rinehart and Winston, Inc., 1966.

Fraser, Stewart ed. American Schools in Foreign Perspectives. New York: John Wiley and Sons Inc., 1969.

Hunt, F. J. ed. Social Science and the School Curriculum. A Report on the Monash Project. Melbourne: Angus and Robertson, 1971.

Knight, Thomas J. "Is Our History Obsolute?" Educational Digest. No. 35, May 1970, pp. 28-31.

Lamb, Winston H. "Planning a History Course - The Fenton Mode 1 and Some others" Agora Vol. IV, No. 6, Nov. 1970, pp. 3-16.

Lergessner, James G. "Australian History Teaching." Queensland Teacher's Journa 1. Vo1. 76, No. 4, pp. 142-144.

Maclaine, A. G. and Selby-Smith, R. eds. Fundamental Issues in Australian Education. Sydney: Ian Novak Publishing Company, 1971.

Matriculation Australian History. A Circular to Schools, No. 32, June, 1969. Agora. Vo1. III, No. 2, June 1969. 
Mohony, D. "History's Future in the Secondary School." Historian No. 24 , Oct. 1972 .

Partridge, P. H. "Teaching the Social Sciences." Education News. Vol. XI, No. 6, December 1967.

Remy, Richard. "High School Seniors Attitudes Toward Their Civics and Government Instruction." Social Education. Vol 36, October 1972.

Russe11, G. P. "Programmed Learning: Causes of World War I." Agora Vol V, No. 3, July 1971, pp. 100-109.

Shumis, S. Samuel. "Six Myths which Delude History Teachers." Agora Vo1. VI, No. 3, June 1972.

Tyack, D. B. Turning Points.in American Education History. Waltham, Mass: Blaisde11 Publishing Company, 1967.

Wehlage, Gary. "The Relevance of History." Educational Forum. No. 35, May 1971, pp. 491-501.

West, Peter. "History and Social Sciences: Searching for Objectives." The Forum of Education. Vol. XXXI September 1972.

Worral1, Graeme. "The Interpretation and Use of Documents in History." Agora Vol. IV, No. 1, February 1970, pp. 1-5.

Ford, F. "The Victorian Historical Association and Curriculum Change." Historian No. 24, October 1972.

Graham, J. M. "History." in Teaching about Society. D. G. Dufty ed. Adelaide: Rigby Ltd. 1970.

Hines, Paul. "World History: The Growing Focus on World Cultures." In Social Studies in the United States ed. by Benjamin Cox and Byron G. Massialas, New York: Harcourt, Brace and World, Inc. 1967.

Kimball, Elisabeth G. "A Survey of the Teaching of History and Social Studies in Secondary Schools." School and Society. No. 98, April, 1970 . 


\section{Appendix I}

W. Lamb. "Planning a History Course - The Fenton Model and

Some Others," Agora Vol. IV, November 1970, pp. 3-14

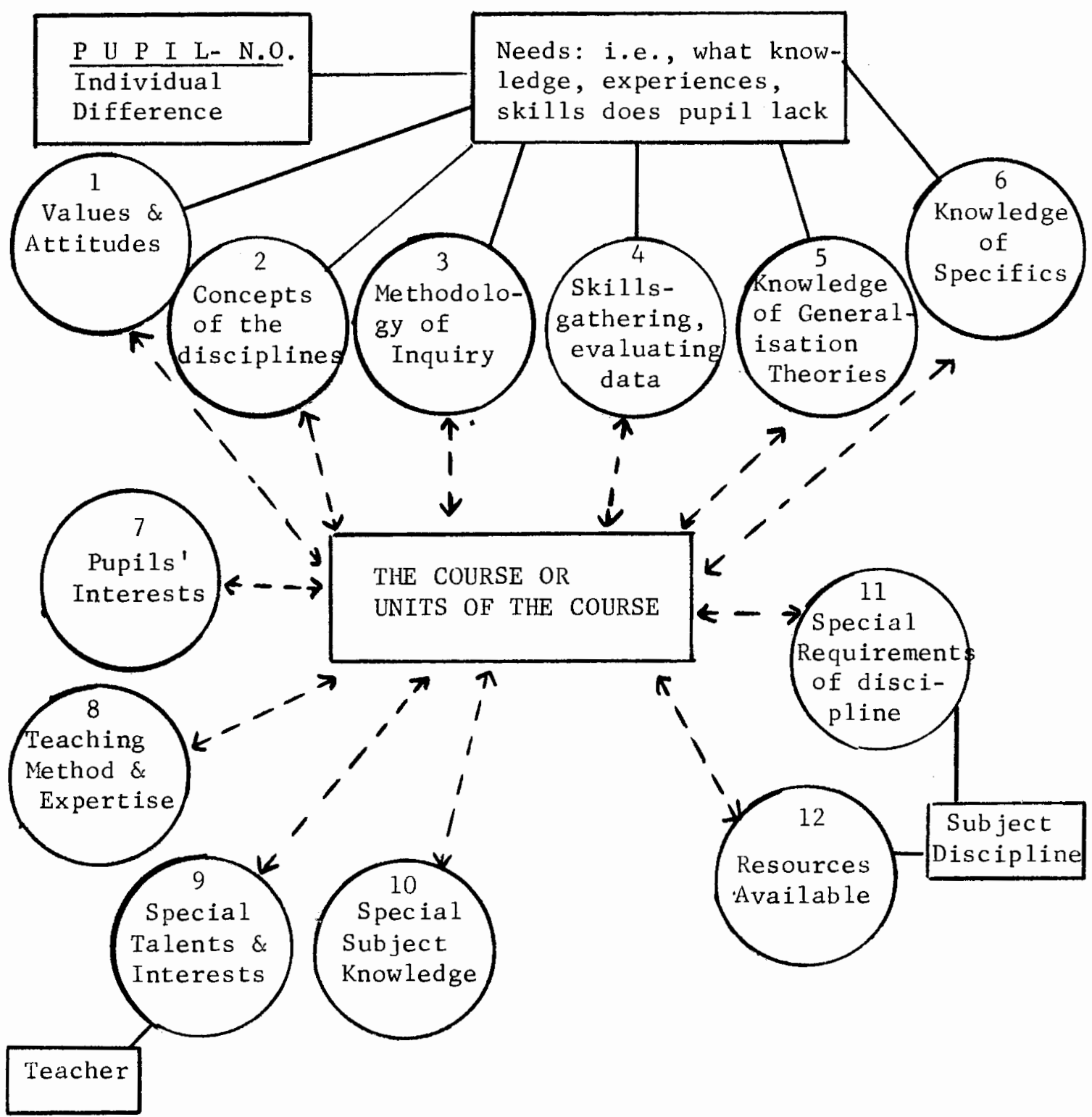

Fig. 1 Elements of the Curriculum 


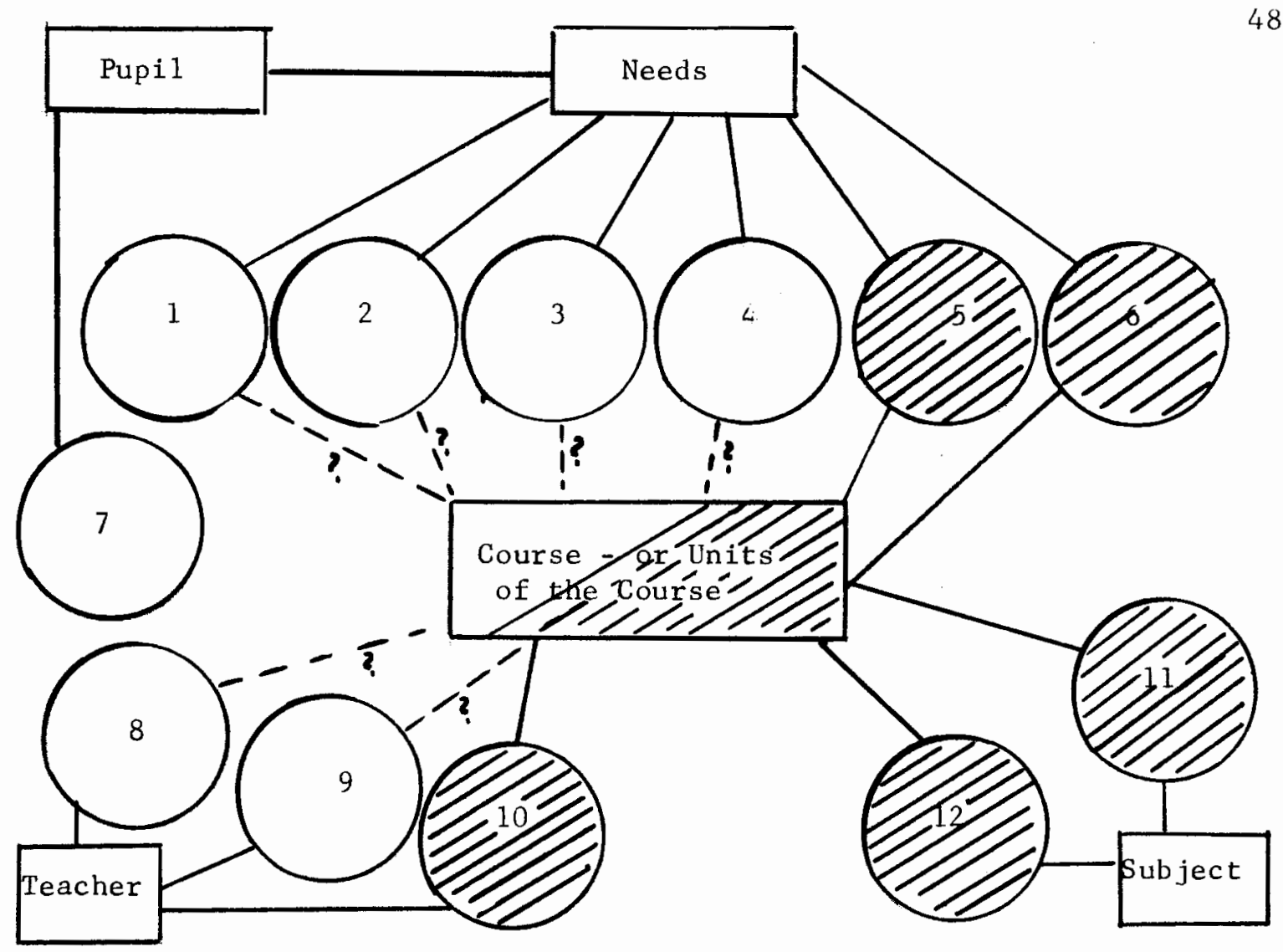

Fig. 2 Traditional Subject-Discipline: Areas of Emphasis

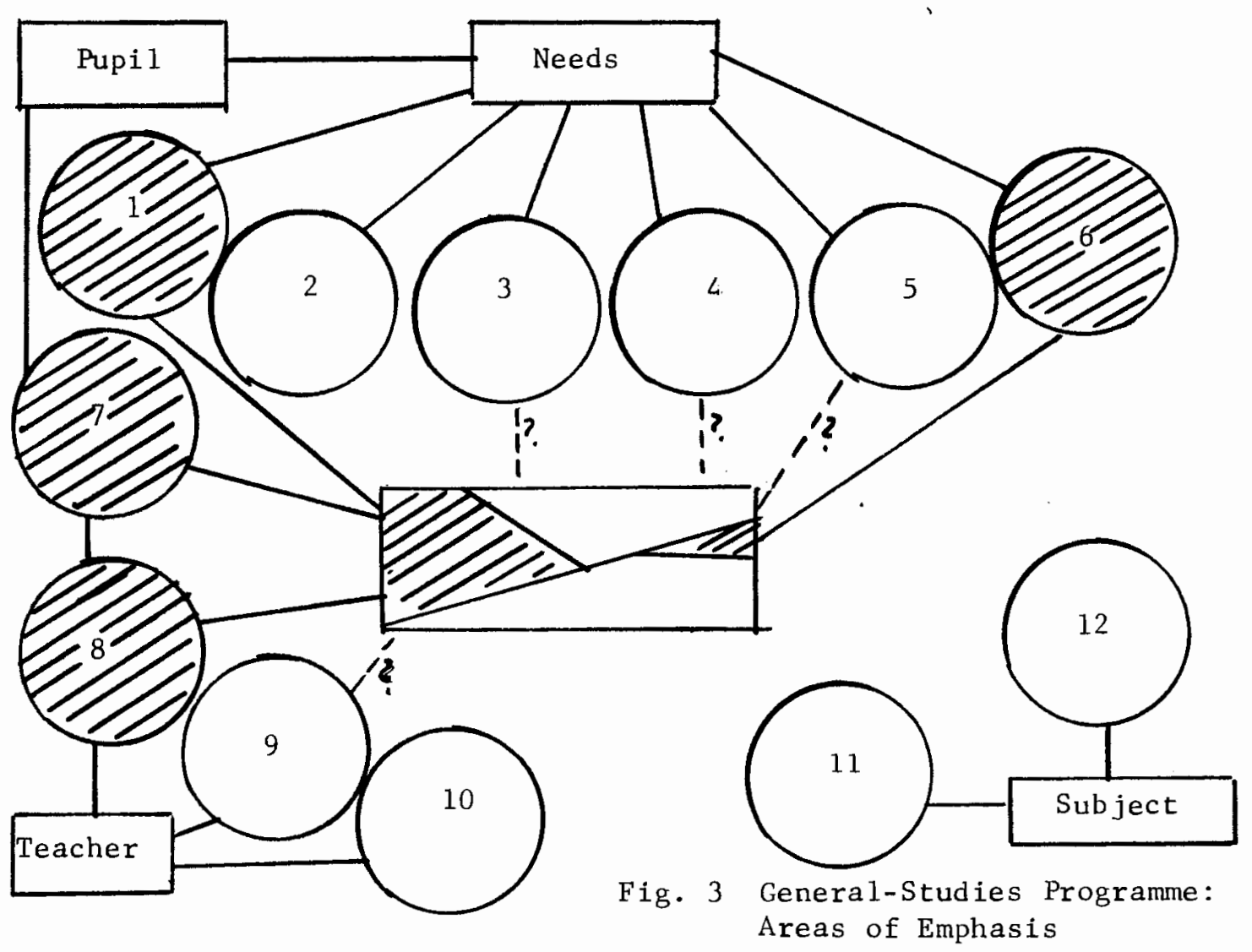




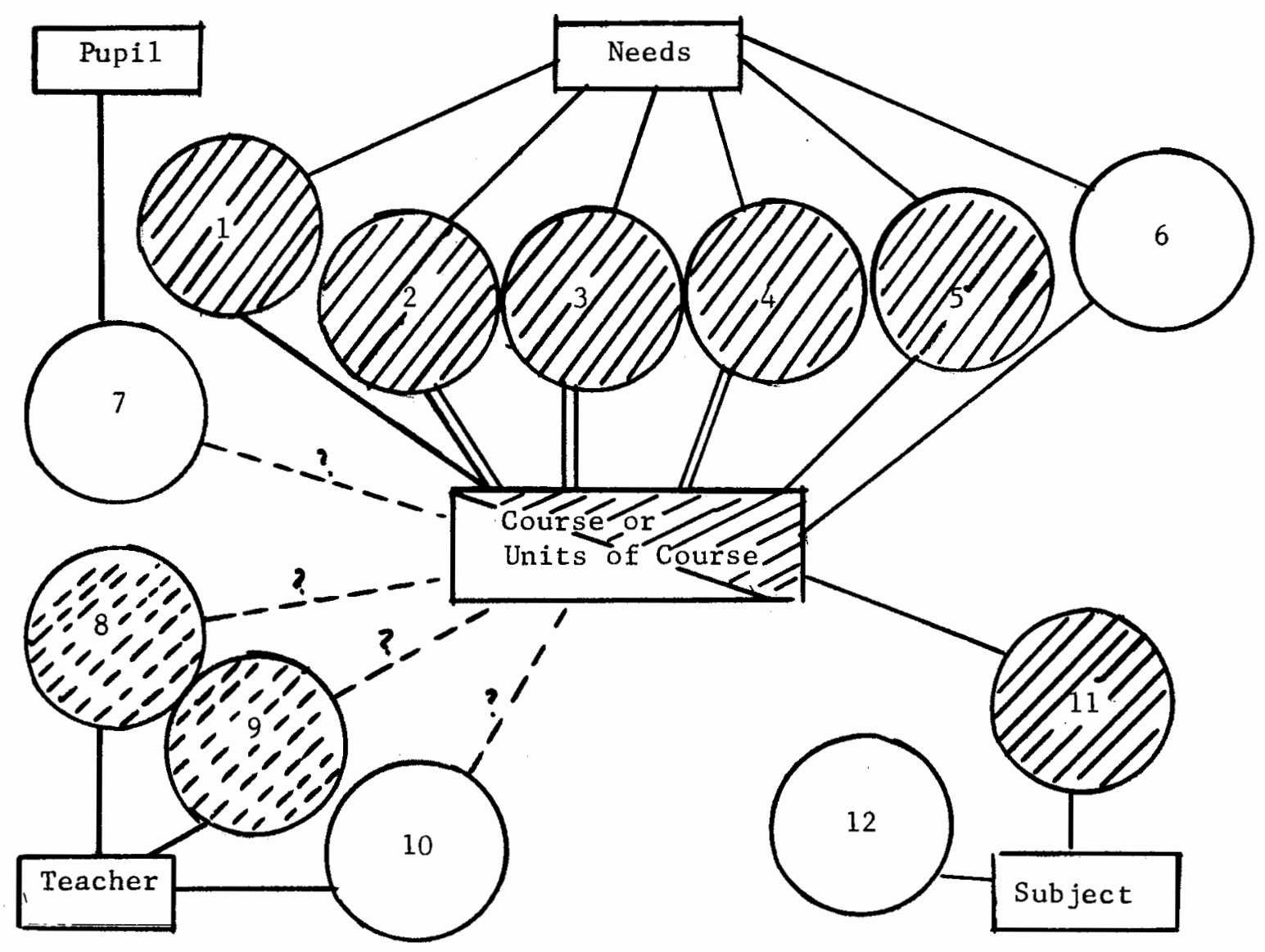

Fig. 4: The Fenton Programme: Areas of Emphasis

The Fenton Course Under Trial in Victoria 
Appendix II

83.

Agora

Volume VII

Number 3

June 1973

TABLE II: *Number of schools \& *percentage of schools taking "traditional" history courses and/or other courses, Forms I - IV, 1972

Form I (258 Schools)

1. Ancient Civilization

2. General Studies

3. Integrated Studies

4. Social Science

5. Other

Form II (254 Schools)

1. British/European History

2. General Studies

3. Integrated Studies

4. Social Science

5. Other

Form III (248 Schools)

1. Australian History

2. General Studies

3. Integrated Studies

4. Social Studies

5. Other

Form IV (245 Schools)

1. Asian History

2. One World Problems

3. Composite One World/Asian

4. General Studies

5. Integrated Studies

6. Social Studies

7. Other

\begin{tabular}{|c|c|c|c|c|c|}
\hline 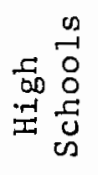 & 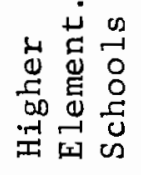 & $\begin{array}{ll}-1 & 0 \\
0 & -1 \\
4 & 0 \\
5 & 0 \\
0 & 0 \\
0 & 0 \\
0 & 0\end{array}$ & 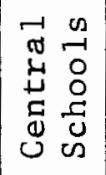 & 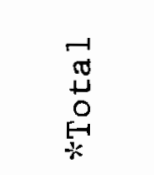 & $\begin{array}{l}00 \\
*\end{array}$ \\
\hline 129 & 3 & 6 & 2 & 140 & 54 \\
\hline 66 & 3 & 2 & 0 & 71 & 28 \\
\hline 17 & 0 & 1 & 1 & 19 & 7 \\
\hline 25 & 1 & 1 & 1 & 28 & 11 \\
\hline 13 & 1 & 0 & 0 & 14 & 5 \\
\hline 155 & 3 & 4 & 3 & 165 & 65 \\
\hline 34 & 3 & 2 & 0 & 39 & 15 \\
\hline 8 & 0 & 1 & 0 & 9 & 4 \\
\hline 33 & 1 & 1 & 1 & 36 & 14 \\
\hline 21 & 1 & 1 & 0 & 23 & 9 \\
\hline 192 & 2 & & 4 & 198 & 80 \\
\hline 13 & 2 & & 0 & 15 & 6 \\
\hline 9 & 1 & & 0 & 10 & 4 \\
\hline 27 & 1 & & 1 & 29 & 12 \\
\hline 15 & 2 & & 0 & 17 & 7 \\
\hline 122 & 1 & & 1 & ( 124 & $(51$ \\
\hline 72 & 3 & $\cdot$ & 0 & $236(75$ & $96(30$ \\
\hline 37 & 0 & & 0 & (37 & $(15$ \\
\hline 7 & 0 & & 0 & 7 & 3 \\
\hline 7 & 1 & & 1 & 9 & 4 \\
\hline 224 & 2 & & 0 & 26 & 11 \\
\hline 14 & 1 & & 1 & 16 & 7 \\
\hline
\end{tabular}


Agora Volume VII Number 3 June $1973 \quad 84$.

TABLE III: Analysis of history courses offered at Form $V \& V i$ levels in Departmental Schools.

\section{Form V (232 Schools)}

1. American History

2. Asian History

3. British History

4. Modern European History

5. GK/Roman History

6. Social Studies

7. Other

Form VI (209 Schools)

1. Asian History

2. Australian History

3. 18th Century - A

4. 18th Century - B

5. European (1300-1600)

6. GK/Roman

7. Social Studies

8. Other

\begin{tabular}{|c|c|}
\hline Tota1s & $\%$ \\
\hline 95 & 41 \\
\hline 51 & 22 \\
\hline 101 & 44 \\
\hline 169 & 73 \\
\hline 1 & 0.4 \\
\hline 58 & 25 \\
\hline 15 & 6 \\
\hline Totals & $\underline{\$}$ \\
\hline 0 & 0 \\
\hline 205 & 98 \\
\hline 64 & 31 \\
\hline 7 & 3 \\
\hline $5 n$ & 27 \\
\hline 1 & 0.5 \\
\hline 66 & 32 \\
\hline 0 & 0 \\
\hline
\end{tabular}


TABLEOF 